Article

\title{
The Regulatory Framework and Minerals Development in Vietnam: An Assessment of Challenges and Reform
}

\author{
Nhi Ba Nguyen ${ }^{1, *(D)}$, Bryan Boruff ${ }^{1}\left(\mathbb{D}\right.$ and Matthew Tonts $^{2}$ \\ 1 UWA School of Agriculture and Environment, the University of Western Australia, \\ Crawley WA 6009, Australia \\ 2 Faculty of Art, Business, Law and Education, the University of Western Australia, \\ Crawley WA 6009, Australia \\ * Correspondence: nhi.nguyenba@research.uwa.edu.au
}

Received: 27 June 2019; Accepted: 26 August 2019; Published: 5 September 2019

\begin{abstract}
This paper aims to identify the key components of a modern mining regulatory framework and examines the extent to which the Vietnamese context reflects these characteristics. Through detailed observation of two research locations in Vietnam-Phuoc Son and Bong Mieu-the paper investigates how national policy operates at a local level. Findings show that, over the past decade, the Vietnamese Government has initiated substantial reforms to the regulatory frameworks governing mining, with the central objective to attract foreign direct investment (FDI). However, it has become apparent that these reforms have numerous deficiencies and loopholes that have led to a range of unintended economic, social and environmental consequences. To cope with challenges such as rent-seeking, limited capacities and capabilities of government staff, failure of institutions and neglect of local communities, policy makers will need to think differently and strategically about the mining industry and how regulations are implemented. Only by addressing these weaknesses will the path be paved for the sustainable growth of Vietnam's mining industry into the future.
\end{abstract}

Keywords: mining; law; regulation; reform; transparency

\section{Introduction}

It has long been acknowledged that resource abundance does not necessarily deliver on the promise of higher economic growth and improved social condition. Lack of transparency and accountability relating to mining revenues is often attributed to poor governance, political instability and corruption [1]. However, the underlying causes of the 'resource curse' are complex and in many instances, sustainable growth and development in resource-rich developing nations has all but failed [2]. To avoid repeating history, regulatory frameworks governing extractive industries in developing nations are required to promote principles of sustainable development [3]. Social scientists and international development organizations Worldbank [4], Cameron and Stanley [5] have worked to improve such frameworks to attract more investments in the mining sector [6] while promoting sustainable development principles to enhance livelihoods, reduce poverty, and ensure ecological health [3]. Debate over the most appropriate regulatory structure persists but, as Onorato et al. [7] argued, modernization of regulatory frameworks [or a Modern Mining code (MMc)] is necessary to ensure fair, transparent, and sustainable outcomes from mining [7].

The notion of a MMc is of particular importance in the developing world where mining has played a crucial role in recent economic growth, but where systematic regulation of the industry has been less successful. For example, in Vietnam, mining accounted for $11 \%$ of Gross Domestic 
Product in 2014 [8] however, conflict over revenues, social upheaval and environmental degradation have plagued the industry [9]. The Government has faced challenges in appeasing commercial mining interests, as well as local stakeholders [10] and, over the past decade, mining governance in Vietnam has experienced extensive reform, with a focus on fostering investment and international competitiveness. New regulations provide guidance for balancing foreign venture and public sector revenue streams [11] yet, deficiencies have been identified that impact both governance structures and sustainable development [4]. For example, Murfitt [12] and MONRE et al. [13] suggest that current regulations are overly complicated and have resulted in inconsistencies in how policies are interpreted and applied. High levels of taxation lead to Government agencies working to 'safeguard' their piece of the revenue pie [12] with a bias towards State-owned Enterprises (SOEs) [4] and a disregard for local communities [13]. There is concern that Vietnam's attempt at a revised regulatory framework (or $\mathrm{MMc}$ ) has not resulted in fair, transparent, and sustainable outcomes for its people.

Onorato et al. [7] have noted that nations with a successful and sustainable mineral sector have adopted "well-articulated policies and legal institutional frameworks which support small and large scale mining operations without imposing uneconomic fiscal burdens" (p. 14). To this end, a MMc should account for the following essential elements: A defined scope of law and institutional framework, participation from all stakeholders, access to mining activities and security of tenure, clarity of obligations of all parties, and adoption of best practice for addressing environmental and social issues [7]. However, the concept of a MMc remains abstract and questions persist concerning what constitutes a well-articulated MMc? Furthermore, once articulated, there is a paucity of approaches for examining the extent to which a country like Vietnam adheres to a modern regulatory structure.

To address these issues, this paper aims to identify the characteristics of a modern mining regulatory framework $(\mathrm{MMc})$ and examine the extent to which the Vietnamese context reflects these characteristics. To do so, we first provide a short review of regulatory reform in the mining sector followed by an overview of the MMc concept. Next, we examine Vietnam's current regulatory structure through the lens of an MMc. We then consider the situation of two locations in Vietnam-Phuoc Son and Bong Mieu —as a means to examine how national policy is reflected at a local level. Finally, a discussion is provided concerning how Vietnam's mining regulations are applied, violated and enforced with a reflection on how conditions may be improved.

\section{Mining Regulations in Vietnam and Beyond}

\subsection{Towards a Modern Mining Code}

Over the last century, mining regulations in developing nations have focused on either enhancing state control of resource revenues or private sector independence [14]. Between the 1940s and 1970s, the former became the precedent with a major focus on concentrating control with the state resulting in an oversight of critical issues including resource rents, job generation, technological transfer, and socio-economic development [14]. By the 1980s, the pendulum had swung the other way with an enhanced focus on reducing state control [14] in order to promote investment, increase job creation and unlock economic growth $[15,16]$. However, the emergence of the 'sustainable development' agenda (see Brundland Report) in the 1990's, placed renewed pressure on development practices calling for economic growth whilst maintaining environmental resources for future generations.

To ensure environmental protection under an agenda of 'sustainable development', environmental impact assessment (EIA) became widespread practice [17] however, the process initially lacked a human focus later countered by a global push for the rights of Indigenous peoples [18]. The right to free, prior, and informed consent (FPIC) [18] argued that Indigenous peoples had land rights that were often usurped by Governments for the benefit of mining [19]. Reflection on industry practices in the last decade has led to a strong focus on Corporate Social Responsibility (CSR), transparency and accountability [20] championed in part by the EITI, the Global Mining Initiative, and the International Council on Mining and Metals [21]. 
Corporate Social Responsibility, and the positive incremental changes that have occurred across the mining sector over the last several decades have coalesced as what could be considered a 'Modern Mining code' which provides an ethical framework for large-scale private investment [15]. Built on strategies developed in Latin America and the Caribbean in 1996, governments have been challenged with remaining transparent, providing stable institutional arrangements, investment certainty, and fiscal responsibility whilst mining companies have been charged with increasing consultation with affected people and mitigating negative social, economic and environmental impacts [7]. Drawing on guidance from these initiatives $[4,5,22]$ and relevant literature $[6,23-28]$ a code to modern day mining practices can be organized around 10 main themes including: Legal frameworks, economic and fiscal policies, institutional reforms, CSR and participation of affected peoples, access to mining activities, ongoing obligations, regulatory aspects, ancillary licenses and permits, investment contracts, and environmental and social matters (Table 1). These criteria establish the foundation for what can be considered a MMc and provide a lens through which Vietnam's current mining context was examined.

Table 1. Summary of the essential elements of a MMc and components of each.

\begin{tabular}{|c|c|}
\hline Element & Component \\
\hline Legal frameworks & $\begin{array}{l}\text { - } \quad \text { Clarity and consistency across legislation. } \\
\text { - } \quad \text { Legislation equally applied to all investors. } \\
\text { - } \quad \text { Long-term security of tenure (20-30 years for exploitation with renewal). } \\
\text { - } \quad \text { Minimum work commitments. }\end{array}$ \\
\hline Economic and fiscal policies & $\begin{array}{l}\text { - } \quad \text { Macroeconomic policies. } \\
\text { - } \quad \text { Access to foreign exchange funds. } \\
\text { - } \quad \text { Profit-based taxes (over royalty taxes, export taxes or import duties). }\end{array}$ \\
\hline Institutional reforms & $\begin{array}{l}\text { - } \quad \text { Government initiative in privatisation of state-controlled mining companies. } \\
\text { - } \quad \text { Elimination of political pressure on private management practices. } \\
\text { Establishment and enforcement of realistic environment, health and } \\
\text { safety regulations. } \\
\text { - } \quad \text { Regulation of artisanal mining. }\end{array}$ \\
\hline
\end{tabular}

\begin{tabular}{|c|c|c|}
\hline $\begin{array}{l}\text { Corporate Social Responsibility(CSR) } \\
\text { and participation of affected peoples }\end{array}$ & $\begin{array}{l}- \\
- \\
-\end{array}$ & $\begin{array}{l}\text { Stakeholder engagement in translation of resources into wealth, economic } \\
\text { development and social empowerment. } \\
\text { Adoption of CSR codes as a supplement to national regulatory schemes. } \\
\text { Provision of mechanisms for arbitration of impacts to local people. } \\
\text { Normalisation of the use of free, prior and informed consent (FPIC) } \\
\text { Addresses Indigenous rights and resettlement issues. }\end{array}$ \\
\hline Access to mining activities & - & $\begin{array}{l}\text { Identification of mining rights and exclusion areas. } \\
\text { Specification of conversion rights. } \\
\text { Provision of prospecting rights. }\end{array}$ \\
\hline Ongoing obligations & - & $\begin{array}{l}\text { Specification of mining company obligations. } \\
\text { Provision of Force Majeure relief. }\end{array}$ \\
\hline Regulatory aspects & - & $\begin{array}{l}\text { Stipulation of rights of regulatory authorities to access, inspect and } \\
\text { issue direction. } \\
\text { Provision of sufficient regulatory powers to ensure mine safety and } \\
\text { proper practices. }\end{array}$ \\
\hline Ancillary licenses and permits & - & Legislates right to operate. \\
\hline
\end{tabular}


Table 1. Cont.

\begin{tabular}{ccl}
\hline Element & \multicolumn{1}{c}{ Component } \\
\hline Investment contracts & - & Provision for modification of mining laws. \\
\hline Environmental and Social matters & - & $\begin{array}{l}\text { Provision for assessment, monitoring and mitigation of } \\
\text { environmental impacts. } \\
\end{array}$ \\
& - & $\begin{array}{l}\text { Safeguards the environment, and human health and safety. } \\
\text { Provision of compliance incentives. }\end{array}$ \\
\hline
\end{tabular}

(Source: $[4,6,7,15,16,21,27-29])$.

\subsection{Vietnamese Mining Regulations}

The current Vietnamese mining context can be attributed to the 2010 Mineral Law. Effective as of 1 July 2011, the regulations replaced the Mineral Law of 1996 and amendments passed in 2005 [30]. According to Fong-Sam [31], the new law protects unexploited minerals, regulates mineral exploration and mining, and provides for the management of minerals located within Vietnam's boarders. The law also reforms the process for acquiring mining licenses and sets forth the financial commitments of the license holder and provides a fundamental framework to guide government agencies in the management of the mining sector as a whole. The nation's regulations are established through a number of resolutions, decrees, decisions, circulars and provincial plans (Table 2). Government agencies tasked with enforcing these regulations are varied and include the Politburo, the Office of the Prime Minister, a number of Ministries including Natural Resources and the Environment; Industry and Trade; Commerce; Construction; Planning and Investment; Finance; and a number of Provincial Authorities (Supplementary Materials 1).

Table 2. Vietnamese government agencies and their key responsibilities in managing the nation's mining sector.

\begin{tabular}{|c|c|}
\hline Government Agencies & Responsibilities \\
\hline $\begin{array}{c}\text { Ministry of Natural Resources and } \\
\text { Environment (MONRE) }\end{array}$ & 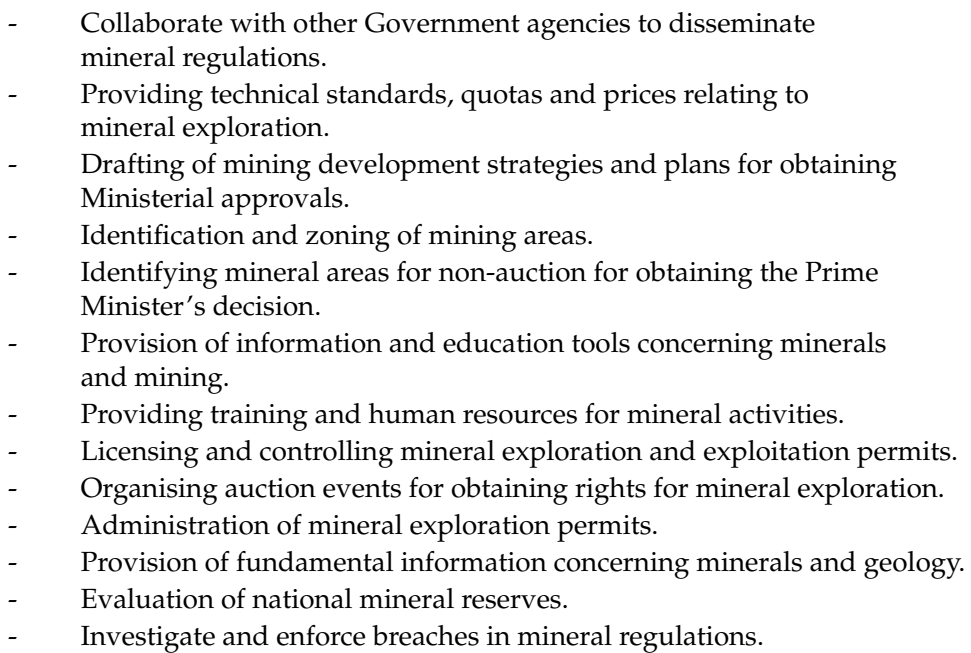 \\
\hline
\end{tabular}


Table 2. Cont.

\begin{tabular}{|c|c|}
\hline Government Agencies & Responsibilities \\
\hline Ministry of Commerce (MOCOM) & $\begin{array}{l}\text { - Collaborate with other Government agencies to disseminate information } \\
\text { concerning mineral regulations. } \\
\text { - } \quad \text { Implementation and oversight of exploitation plans, processing and } \\
\text { utilisation of minerals after obtaining approval. } \\
\text { Oversight, guidance, investigation and monitoring of policies, technical } \\
\text { standards, occupational health and safety }(\mathrm{OSH}) \text { regulations, } \\
\text { and environmental protection in mineral processing and exploitation. } \\
\text { Evaluation and monitoring of facilities used for mineral exploitation } \\
\text { and processing. } \\
\text { Categorisation of minerals, and enforcement and oversight of mineral } \\
\text { export policies. }\end{array}$ \\
\hline $\begin{array}{l}\text { Ministry of Construction } \\
\text { (MOCON) }\end{array}$ & $\begin{array}{l}\text { - } \quad \text { Collaborate with MONRE for drafting national mineral strategies. } \\
\text { Collaborate with MONRE and related Ministries to enact mineral } \\
\text { regulations including auctioning of mineral exploitation rights, } \\
\text { and establishment of fee schedules and tax policy. } \\
\text { - } \quad \text { Collaborate with MONRE and MOCON to manage mineral resources. } \\
\text { - } \quad \text { Obtaining Ministerial approval concerning the use of minerals in } \\
\text { construction and the exporting construction related minerals. }\end{array}$ \\
\hline $\begin{array}{l}\text { Ministry of Planning and } \\
\text { Investment (MPI) }\end{array}$ & $\begin{array}{l}\text { - } \quad \text { Collaborate with MONRE for drafting national mineral strategies. } \\
\text { Collaborate with MONRE and related Ministries to enact } \\
\text { mineral regulations. } \\
\text { - } \quad \text { Participate in the evaluation and adjustment of development plans for the } \\
\text { mining industry including environmental protection. } \\
\text { - Collaborating with MONRE and MOCON to manage the mineral resources. } \\
\text { - } \quad \text { Participate in the licensing mineral exploration and exploitation projects. } \\
\text { - } \quad \text { Work with domestic and foreign investors to adhere with Investment Law. }\end{array}$ \\
\hline Ministry of Finance (MOF) & $\begin{array}{l}\text { - Collaborate with related Ministries to enact regulations including: Decree } \\
\text { 22/2012/ND-CP, procedures of capital contributions, management of capital } \\
\text { contributions of individuals and organisations relating to mineral } \\
\text { exploration, and taxes for natural resources. } \\
\text { Enact regulations regarding fees for mineral exploitation, and management } \\
\text { and utilisation fees. } \\
\text { Managing the State budget for mineral activities. }\end{array}$ \\
\hline $\begin{array}{l}\text { Provincial People's Committee } \\
\text { (PPC) }\end{array}$ & 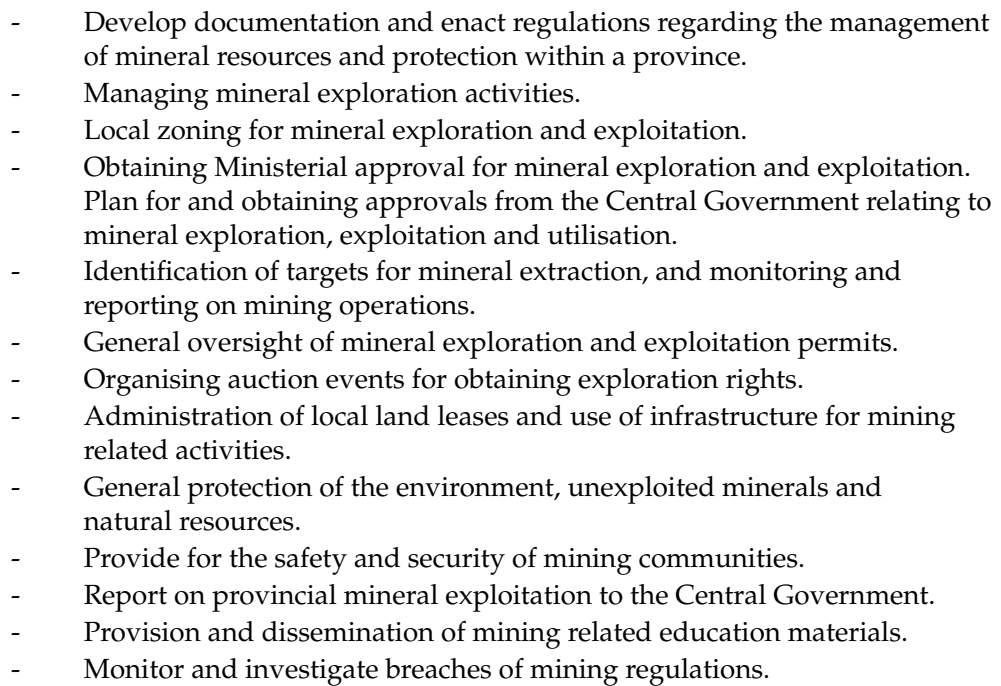 \\
\hline
\end{tabular}


Table 2. Cont.

\begin{tabular}{ccl}
\hline \multicolumn{1}{c}{ Government Agencies } & \multicolumn{1}{c}{ Responsibilities } \\
\hline & - & $\begin{array}{l}\text { In conjunction with PPC, administer of local land leases and use of } \\
\text { infrastructure for mining related activities. }\end{array}$ \\
Commune and District People's & - & $\begin{array}{l}\text { General protection of the environment, unexploited minerals and } \\
\text { natural resources. }\end{array}$ \\
Committee (CPC and DPC) & - & $\begin{array}{l}\text { Provide for the safety and security of mining communities. } \\
\text { Report to the PPC on matters concerned with mineral exploration at the } \\
\text { commune/district level. } \\
\text { Provision and dissemination of mining related education materials. }\end{array}$ \\
& - & Monitor and investigate breaches of mining regulations. \\
\end{tabular}

(Source: [32,33]).

The last decade has brought forth substantial reform to Vietnam's mining regulations resulting in a number criticisms, including rising levels of taxation [34] and disregard for the needs of local communities [35]. Although the nation's mining sector is regulated by the central government, natural resource taxes and revenues from mining related businesses provided significant contributions to regional government budgets [36]. The text that follows presents an analysis of the extent to which Vietnam's current regulatory reform reflects a MMc and how these regulations have been applied, violated and enforced.

\section{Methods}

To examine the policy implications of Vietnam's national regulatory reform, this paper draws on earlier work in the Quang Nam Province (see [36]) and in particular two gold mines operated by the Canadian firm Besra; Phuoc Son mine, located in Phuoc Duc commune, Phuoc Son district in the western highlands of Quang Nam province, and the Bong Mieu mine, located in Tam Lanh Commune, Phu Ninh district in the southeast corner of Quang Nam province. Gold extraction in the Phuoc Son and Bong Mieu regions has a long history. The first gold mining activities in Phuoc Son were undertaken during French occupation from 1857 to 1945 [37]. In contrast, gold mining activities commenced in Bong Mieu almost 50 years later under the direction of French in 1895. When the Vietnamese-American war ended in 1975, Bong Mieu was taken over and managed by the Vietnamese government [38].

Regulatory analysis was employed to understand the extent to which Vietnam's mining regulations reflect an MMc. This included a detailed assessment of key legal documents (such as the 2010 Mineral Law-see Supplementary Materials 1 for full list), regulatory frameworks, policy documents and specific mining agreements. At the provincial level, data including tax and land allocations were gathered from the Quang Nam People's Committee and related agencies during field visits. Next, structured and semi-structured interviews, and small group discussions collected during extensive fieldwork in 2016 (see [36]) were used to examine how the nation's regulatory reforms have manifest at the local level, particularly in Phuoc Son and Bong Mieu gold mines in Quang Nam province which were operated by the Canadian firm, Besra (Figure 1).

An overview of participants interviewed during field visits are presented in Table 3. Community members provided insight into the local impacts of mining related activities, while regional authorities and mining management shared their concerns over the influence of policies and management strategies employed by the federal governmental. 


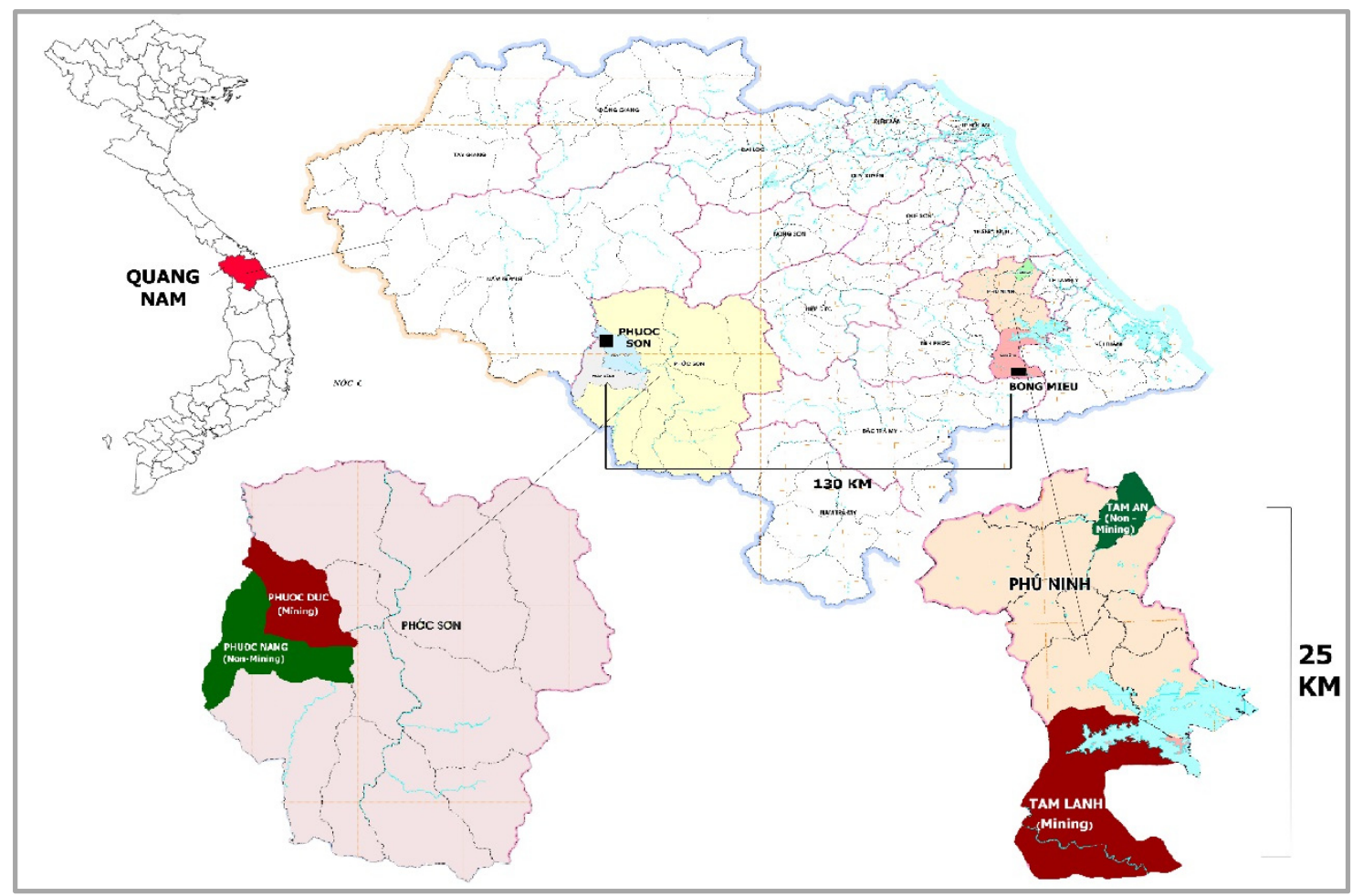

Figure 1. Research locations in Phuoc Son and Phu Ninh districts, Quang Nam province (As seen in [36]).

Table 3. Number and affiliation of study participants.

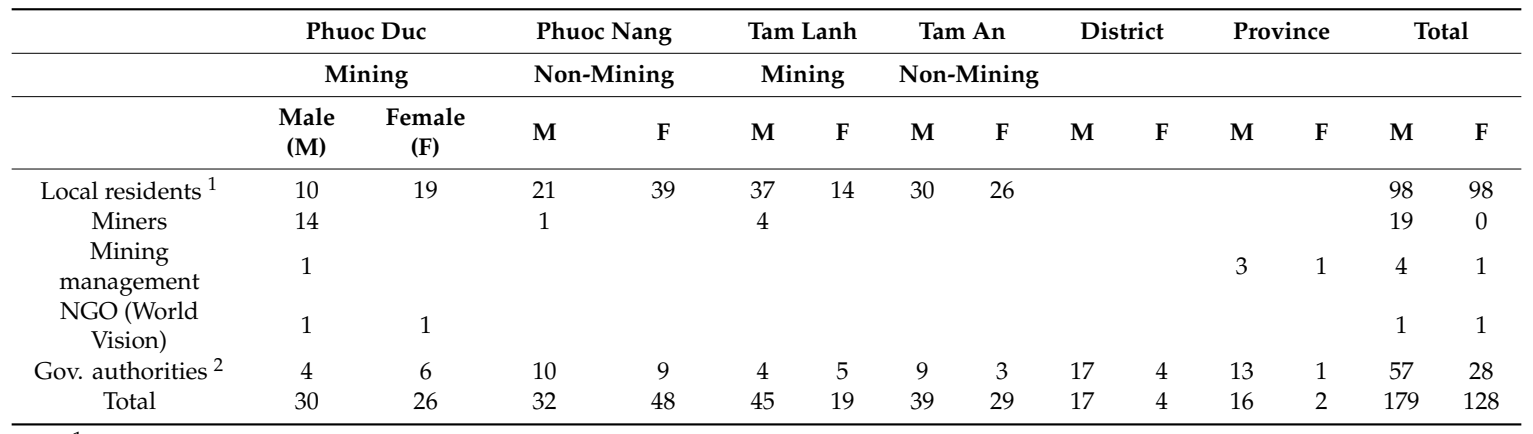

${ }^{1}$ Local residents representing farmers, fisherman, traders, students, the elderly, housewives and unemployed persons. ${ }^{2}$ Government authorities included the People's Committee and the Departments of Natural Resources, Agriculture, Investment, Planning, Social Affairs, Indigenous and Culture, Education and Health and Infrastructure.

\section{The Modern Mining Code and Regulatory Reform in Vietnam}

Table 4 provides an overview of the results of a critical analysis of Vietnam's mining regulations. In the first instance, Vietnam's regulatory framework has been enhanced with a number of protections for mining companies including long-term security of tenure, commitments to exchange, and a guarantee to privatize state owned assets and secure mining rights. In terms of Corporate Social Responsibility, policies address health and safety regulations as well as resettlement issues; however, there are a number of areas where the nation's regulatory framework lacks transparency, is overly complicated, and/or constrains a company's ability to operate efficiently. These results are explored more fully in the following sub-sections. 
Table 4. Summary of essential elements and indicators of an MMc, with a critical analysis of Vietnam's mining regulations.

\begin{tabular}{|c|c|c|}
\hline MMc Element & MMc Indicator & Achievements and Deficiencies \\
\hline \multirow{4}{*}{$\begin{array}{l}\text { 1. Legal } \\
\text { frameworks }\end{array}$} & $\begin{array}{l}\text { 1.1. Clarity, constancy, minimal discretion and } \\
\text { coordination }\end{array}$ & $\begin{array}{ll}\text { - } & \text { Overly complicated } \\
\text { - } & \text { Difficult to understand } \\
\text { - } & \text { Policy inconsistencies }\end{array}$ \\
\hline & 1.2. Applying equally to all investors & $\begin{array}{l}\text { - Priorities and privileges to } \\
\text { SOEs and related-SOEs }\end{array}$ \\
\hline & 1.3. Long-term security of tenure & $\checkmark$ \\
\hline & 1.4. Guarantee of commitments in exchange & $\checkmark$ \\
\hline \multirow{3}{*}{$\begin{array}{l}\text { 2. Economic and } \\
\text { fiscal policies }\end{array}$} & $\begin{array}{l}\text { 2.1. Promote good macroeconomic policy and } \\
\text { governance }\end{array}$ & $\begin{array}{l}\text { - Inconsistent mining regulations } \\
\text { - Illogical economic policies } \\
\text { - } \text { Prevalence of corruption } \\
\text { - } \text { Ineffective management }\end{array}$ \\
\hline & 2.2. Foreign exchange access & $\checkmark$ \\
\hline & $\begin{array}{l}\text { 2.3. Focusing on earning-based taxes and decrease } \\
\text { operating losses }\end{array}$ & $\begin{array}{l}\text { - } \quad \text { Does not identify natural } \\
\text { resource tax for a specific mineral } \\
\text { - High taxes } \\
\text { - Tax calculated by volume and } \\
\text { quality of ores }\end{array}$ \\
\hline \multirow{5}{*}{$\begin{array}{l}\text { 3. Institutional } \\
\text { reforms and } \\
\text { infrastructure }\end{array}$} & $\begin{array}{l}\text { 3.1. Responsibility of Government for privatisation } \\
\text { of SOEs }\end{array}$ & $\checkmark$ \\
\hline & 3.2. Elimination of political pressure & $\begin{array}{l}\text { - "Master plans" created by the } \\
\text { Government } \\
\text { - Privileges to SOEs } \\
\text { - Numerous Governmental } \\
\text { agencies involved with } \\
\text { management } \\
\text { - Bureaucracy } \\
\text { - Lack of transparency } \\
\text { - Breaches of licensing process } \\
\text { - Corruption and rent-seeking } \\
\text { behaviour }\end{array}$ \\
\hline & 3.3. Health and safety regulations & $\checkmark$ \\
\hline & $\begin{array}{l}\text { 3.4. Good infrastructure to address environmental } \\
\text { issues }\end{array}$ & $\begin{array}{l}\text { - Further provisions and } \\
\text { clarification required }\end{array}$ \\
\hline & 3.5. Regulate artisanal mining & - Not identified \\
\hline \multirow{6}{*}{$\begin{array}{l}\text { 4. CSR and } \\
\text { participation of } \\
\text { affected peoples }\end{array}$} & 4.1. Development and empowerment & $\begin{array}{l}\text { - Further provisions and } \\
\text { clarification required }\end{array}$ \\
\hline & 4.2. Adopting CSR codes & - Not identified \\
\hline & 4.3. Arbitration of impacts on local peoples & $\begin{array}{l}\text { - Unclear and need further } \\
\text { clarification }\end{array}$ \\
\hline & 4.4. Free, prior, informed consent & - Not identified \\
\hline & 4.5. Address indigenous issues & $\begin{array}{l}\text { - Unclear and unsubstantiated } \\
\text { concerns } \\
\text { - Further provisions needed }\end{array}$ \\
\hline & 4.6. Address resettlement issue & $\checkmark$ \\
\hline \multirow{3}{*}{$\begin{array}{l}\text { 5. Access to mining } \\
\text { activities }\end{array}$} & 5.1. Mining rights & $\checkmark$ \\
\hline & 5.2. Conversion rights & $\checkmark$ \\
\hline & 5.3. Prospecting rights & $\checkmark$ \\
\hline \multirow{2}{*}{$\begin{array}{l}\text { 6. Ongoing } \\
\text { obligations }\end{array}$} & 6.1. Compliance by mining company & $\begin{array}{l}\text { - Increased specificity required } \\
\text { - Ineffective law enforcement }\end{array}$ \\
\hline & 6.2. Provide Force Majeure & $\begin{array}{l}\text { - Not identified } \\
\text { - Clarification of environmental } \\
\text { regulations required }\end{array}$ \\
\hline
\end{tabular}


Table 4. Cont.

\begin{tabular}{|c|c|c|}
\hline MMc Element & MMc Indicator & Achievements and Deficiencies \\
\hline $\begin{array}{l}\text { 7. Regulatory } \\
\text { aspects }\end{array}$ & $\begin{array}{l}\text { 7.1. Stipulate rights of regulatory authority } \\
\text { 7.2. Provide sufficient powers to regulatory bodies }\end{array}$ & $\checkmark$ \\
\hline $\begin{array}{l}\text { 8. Supporting } \\
\text { licenses }\end{array}$ & 8.1. Identify rights of resource use & $\checkmark$ \\
\hline $\begin{array}{l}\text { 9. Investment } \\
\text { contracts }\end{array}$ & 9.1. Provide opportunities to modify or supersede & $\checkmark$ \\
\hline \multirow[t]{3}{*}{$\begin{array}{l}\text { 10. Environmental } \\
\text { and social matters }\end{array}$} & 10.1. Assessing and monitoring mining projects & $\begin{array}{l}\text { - Inconsistent management of } \\
\text { mining tailings } \\
\text { - Lack of responsibility of } \\
\text { relevant agencies } \\
\text { - Noncompliance by mining } \\
\text { companies } \\
\text { - Reclamation and rehabilitation } \\
\text { requirements not met } \\
\text { - Inadequate protection of local } \\
\text { people's property rights. }\end{array}$ \\
\hline & $\begin{array}{l}\text { 10.2. Incorporating safeguard measures for } \\
\text { environment, health and safety }\end{array}$ & $\begin{array}{l}\text { - Inadequate (low) } \\
\text { environmental fee } \\
\text { - Ineffective collaboration among } \\
\text { agencies } \\
-\quad \text { Ineffective monitoring of } \\
\text { transfer tax revenues } \\
-\quad \text { Vulnerabilities to health and } \\
\text { livelihoods }\end{array}$ \\
\hline & 10.3. Compliance incentives and tax deductions & $\begin{array}{l}\text { - } \quad \text { Not identified } \\
\text { - } \quad \text { Low recruitment of local } \\
\text { peoples } \\
\text { - } \quad \text { Ineffective CSR initiatives }\end{array}$ \\
\hline
\end{tabular}

$\checkmark$ Indicates Vietnam's legal framework adequately addresses the issue. (Source: $[4,6,7,15,16,21,27-29]$ ).

\subsection{Complexity and Inconsistency in Regulations}

In the last decade, the Vietnamese Government has made substantial reforms to the regulatory system. However, it remains complicated and difficult to interpret [12,13]. For example, in order to apply the 'Luật Khoáng Sản 2010' [32] (herein referred to as the Mineral Law) in practice, additional legal documents are required including decrees, decisions, circulars, and provincial mineral plans [39]. There have been issues with the release of complementary laws where, for instance, decree 15/2012/ND-CP [40] was not enacted by the Government until nearly a year after the Mineral Law came into effect (National Assembly's Economic Committee) [41] yet is essential in providing guidance for several articles. In addition, since 2010, some policies have been altered, whilst others have not lead to inconsistencies in interpretation and implementation [42].

The Mineral Law has also been described as lacking necessary detail and practicality [41,43]. For example, articles 64 (relating to mineral exploitation for general construction material), 65 (relating to mineral exploitation in areas that have construction projects) and 79 (payment and auction for non-probing mineral areas) are insufficient in properly regulating exploration $[41,43]$ and does not provide guidance for estimating mineral prices for large volumes of materials [44]. In addition, the industry is administered by multiple Government agencies, leading to a complex bureaucracy difficult to navigate [39]. For instance, Dau, Phan [45] identified that in one instance it took two years for a mining company to attain an exploration license requiring approval from several competing agencies. The inefficiency and complexity of these arrangements has been noted by the Environment, Technology and Science Commission of the National Assembly, conceding to a slow approval process (Presented in 1642/BC-UBKHCNMT13/20-7-2015 by Ministry of Natural Resources and Environment. Five years evaluation on implementation of mineral law and regulations [41]. Similarly, there is increasing consensus of a lack of clarity around various agencies responsibilities in managing the 
mining industry [42]. In essence, there is a lack of clarity of how the Minerals Law translates into clear and effective governance.

One of the key weaknesses of the Minerals Law is that it does not reduce the influence of State-owned enterprises (SOEs) which have enjoyed support from the Government through a monopoly on mining related businesses [46]. Dau, Phan [45] indicated that 53\% of mining companies are at least partially controlled by the State and according to the World Bank [47], the Vietnam National Coal-Minerals Industries Corporation (Vinacomin), which is $50 \%$ State owned, is in direct or indirect control of approximately $95 \%$ of Vietnam's hard-rock mineral production. In addition, the Chairman and General Director of Vinacomin was directly appointed by the State [47] increasing federal control over the industry which is in direct conflict with principles of a MMc that seeks to limit state involvement. According to Tran ([46], p. 9), this type of appointment has created "a cosy relationship between business and the government".

\subsection{Licensing and Transparency}

Vietnam's regulatory framework often lacks the tools to prevent breaches. A report penned by MONRE (Report on Natural Resource Management No 3141/BTNMT-PC dated 15/8/2013, MONRE: Ministry of Natural Resource and Environment) indicated that of the 957 mining licenses approved from July 2011 to December 2012, 1086 legal breaches were committed. Noncompliance was also evident at the provincial level [48], where national policy does not authorize the District People's Committees (DPC) or provincial divisions of the Department of Natural Resources and Environment (DNRE) to grant mining licenses. However, investigations found that in several provinces, both the DPCs and DNREs have authorized licenses for small-scale exploration [48], which accounted for more than $50 \%$ of the mining licenses issued in 2013 [49].

Furthermore, current policies do not require transparency of the project bidding process, nor do they require that outcomes of the process are publicized [50]. Companies have noted a lack of information available from the Government, including up-to-date maps and land use planning documentation. According to VCCI [51], 48\% of mining companies had to negotiate with Government agencies just to obtain information to facilitate business opportunities. In addition, Dau, Nguyen [50] argued that a lack of transparency was due to the absence of mechanisms for independent monitoring and dialogue between stakeholders. These deficiencies may be attributed to ineffective regulatory enforcement and Government bureaucracy which has been reflected in the Resource Governance Index for 2013, where Vietnam was ranked 40 out of 58 nations for transparency [52].

\subsection{Corruption and Rent-Seeking}

A lack of effective mechanisms for preventing corruption is one of the most important concerns within contemporary mining regulatory frameworks [45]. This is also the case in Vietnam. A recent investigation into Vietnam's licensing process found that approximately $10 \%$ of fees payed to the Government by mining enterprises (MEs) were 'unofficial' [53]. In addition, VCCI [51] found that in $2013,78 \%$ of MEs had to pay bribes to conduct business in the country. This was confirmed by the Government Inspectorate of Vietnam, who identified that unofficial fees ranged from USD 5000 to 50,000 just for licensing approval [54].

Rent-seeking behavior has also been noted by several scholars [55]. This is framed as 'concealed benefits' gained through collaboration between politicians and mining companies. Moreover, such relationships often underpin oligopolistic or monopolistic outcomes within the industry [56]. According to VUSTA [42] and Vu [57], the phenomenon of "begged-given" (The "Begged-given" phenomenon may be a result of corruption or rent-seeking behavior where a company begs a powerful Government official to obtain a mining license without an auction. In many cases, companies may be uncompetitive or unable to comply with legal procedures [57] (cơ chê "xin-cho" in Vietnamese) has been identified in Vietnam where poorly qualified mining enterprises are granted mining licenses in return for a portion of their revenue. Corruption in regard to licensing has also resulted in mining firms operating without 
appropriate technical and financial capabilities [42]. Consequently, financial and human resources have been wasted due to inefficient extraction processes in locations were rich deposits are easily accessed. Numerous issues have been associated with unqualified firms including environmental pollution, infrastructure degradation and social upheaval [58].

\subsection{Tax Regulations}

Field observation and research indicated that Vietnam's current mining regulations have resulted in one of the most heavily taxed extractive sectors globally [12,57]. In June 2008, the removal of value-added tax (VAT) incentives resulted in mining companies' inability to process minerals economically, as VAT refunds were often built into costing models [34]. In addition, export tariffs on many ores increased from $5 \%$ to $20 \%$, royalty rates increased from $5 \%$ to $7 \%$ for the majority of minerals, and $6 \%$ to $9 \%$ for gold [34]. The corporate income tax increased from $32 \%$ to $52 \%$ for projects commencing after January 2009 [34] and by 2016, the Government had increased the natural resource tax by $2 \%$ with the addition of several new fees under the guise of environmental protection and exploitation rights [59].

$\mathrm{As} \mathrm{Vu}$ [57] identified, taxes are not consistent within or across mineral groups. For example, coal is taxed between $4 \%$ and $20 \%$, metals between $7 \%$ and $25 \%$ and non-metals between $3 \%$ and $15 \%$ [ 41 ]. In addition, NAEC [41] identified that the mineral exploitation tax structures has impacted on how firms operate. Overlaps have been identified between the fees for exploitation rights (FER) (article 77 of the Law), resolution 203 [60], circular 54 [61] and the natural resource tax (NRT) (article 4 of the Natural Resource Tax Law 2009). In essence, FER and NRT are one in the same, but according to regulations, NRT is regarded as an additional tax [41].

\subsection{Environmental Protection}

The Government has enacted legislation enhancing environmental protection including Article 3 of the Mineral Law, Article 38 of the Environmental Law [62], decision 18 [63], and circular 38 [64]. However, resource extraction is still acknowledged as one of the key drivers of environmental degradation [9], forest clearing [65], production of mine tailings and other wastes [42], and water pollution [4]. Furthermore, MONRE [66] identified that environmental laws do not clearly stipulate who is responsible for certain aspects of environmental protection. There is confusion over the responsibilities of the Ministry of Construction and the Ministry of Commerce in terms of solid waste management. For example, circular 81 [67] identifies that the Provincial Department of Natural Resources and Environment is responsible for environmental protection, including management of solid waste, yet circular 13 [68] states that the Provincial Department of Construction is responsible for the same waste products. The result is that solid waste across Vietnam is managed by different Government agencies in different provinces and to different standards.

Enforcing the environmental regulations that do exist is often problematic under the current system. According to VUSTA [42], the management, implementation and monitoring of mines must be stipulated in individual Environmental Impact Assessments (EIAs) yet, this has proven ineffective. According to the World Bank [47], since legal frameworks do not provide guidelines for evaluating EIAs, mining companies are likely to prepare insufficient reports addressing only the minimum legal requirements. An assessment of mining operations in Quang Ninh province found that only 38 out of 68 coal mines had prepared EIA reports and few were updated when changes in production had occurred, despite being required by law [47].

Policies regulating mine reclamation have also been exploited by resource companies. According to decision 71 [69], mining companies are required to pay a bond for environmental rehabilitation. However, enforcement does not always occur and when mines close, funds are not available for rehabilitation [42]. Government agencies have identified that it is difficult to manage how bonds are spent as guidance is limited and according to circular 63 [70], mining companies must pay 
environmental fees varying from VND 10,000 (USD 0.5) to VND 180,000 (USD 9) per cubic meter or ton mined and these fees are often insufficient [47].

\subsection{Societal Impacts}

According to circular 74 [71] and the Law on the State Budget 2015, mining regions should receive $100 \%$ of the natural resource tax and the environmental fees for socio-economic development and environmental protection. However, it is difficult to determine if these fees are being appropriated to the regions and if they are being used as intended. Dau, Phan [45] identified that, in particular, auditing environmental fee expenditures has been difficult and unclear if local people have benefitted. For example, it was reported that a mining company had contributed VND 36 billion (USD 1.8 million) in taxes to the Central Government but the region where the company was operating had not seen any revenue [35].

Property rights, particularly in relation to agricultural land, have not been adequately accounted for either [72]. For instance, Tran, Nguyen [35] indicated that across five mining sites, 188 households had lost 470 ha of agricultural land adversely affecting livelihoods. Local land owners have lost considerably to mining through a lack of appropriate compensation (50-70\% of the market prices) and are often deficient in skills needed to lobby for fair compensation [35].

Furthermore, ambiguity in the wording of one particular regulation has protected mining companies from being required to recruit local labor. The Mineral Law, for instance, legislates that mining companies must 'prioritize' the use of local labor however; the engagement of local people in resource projects has often fallen well below expectations. In the five mining projects examined by Tran, Nguyen [35], the proportion of local people recruited at each site accounted for between $0.6 \%$ and $1.8 \%$ of all employees. When employed, local people were found to work as casuals resulting in low incomes, instability, and a lack of insurance coverage [35].

Mining regulations are also insufficient for covering health impacts on local residents. For example, Tran, Nguyen [35] noted that $4-5 \%$ of the population at one mine were infected with tuberculosis and $60 \%$ of the population suffered from bronchitis. Residents surrounding one lead mining project, reported dizziness, vomiting, difficulty breathing, chest pain, dermatological issues, high blood pressure, and joint and eye diseases [73]. The Mineral Law stipulates that it is the responsibility of mining companies to support local communities in terms of infrastructure development, social welfare and environmental restoration however, this is not monitored effectively [43].

\subsection{Improvements to Mining Regulations}

While a critical review of Vietnamese regulatory reform is presented above, there have been a number of improvements to the mining governance processes. More security is now provided for investors (decree 158/2016/ND-CP) and financiers are now provided an opportunity to bid for exploration rights, an opaque process before reform was enacted. Similarly, “Decree 250/2010/ND-CP on royalties represents a major step forward for the gold mining industry in Vietnam, and also provides some much needed relief from what was the highest taxing mining jurisdiction in the world" ([74], p.1). Regulatory reform has also improved opportunities for mining enterprises to access land tenure information, government maps, and other related planning information necessary to make sound investments decisions [51]. Environmental protection, licensing, mining rights and access to mining activities are all addressed by Mineral Law 2010 and/or supporting documents providing added security and transparency for all parties.

According to the Ministry of Environmental and Natural Resources [33], six key improvements to mining regulations have been realized. In the first instance, consistency among policies has been improved within a regulatory system that now provides oversight across the entire mining sector. The roles and responsibilities of governmental agencies have been more clearly defined with MONRE acting as the central administrative body for the mining industry. Geologic mapping has been completed for all of Vietnam and a licensing process has been put in place to manage exploration. 
Finally, foreign direct investments are now encouraged by the federal government in combination with transparent taxation rates and royalty payment schemes.

\section{Mining Legislation at the Local Level}

\subsection{Fees and Taxes}

While the majority of mining policies are administered by the Central Government, particularly resolutions 02 (Resolution 02-NQ/TW/2011, strategy for the mineral industry to 2020 and a vision to 2030.) and 103 [75], and decision 2427 [76], there are provincial policies that influence operations on the ground. For example, in Quang Nam province, the Provincial Standing Committee's Action Plan (18/CTr/TU/2012, action plan to implement Resolution 02-NQ/TW/2011) provides a framework strategy and vision for the Province's mineral sector for 2020 and beyond.

According to two resolutions 928 and 712 [77], taxes on gold should be levied at a rate of $15 \%$ however, based on the Quang Nam People's Committee's (QNPC) decision (22/2013/QD-UBND, natural taxes on Quang Nam province.), gold with a purity of $98 \%$ is taxed at a rate of VND 1,000,000 (estimated USD 50) per gram. In contrast, an environmental protection fee (EPF) administered by Quang Nam province align closely with that of the Central Government which is likely to benefit mining companies.

Indeed, there is a clear focus on ensuring that the region receives return on investment. According to QNPC's decisions (32/2010/QD-UBND and 31/2013/QD-UBND: Revenue retention and budget allocation), the districts retains $80 \%$ of the environmental protection fee (EPF) and $100 \%$ of taxes levied on extracted resources. Information collected during interviews revealed that taxes from Bong Mieu mine accounted for 15\% to 20\% of Phu Ninh's revenue from 2010-2013. In 2011 and 2012, Phuoc Son district earned approximately USD 6.5 million from the EPF and natural resource tax however, transparency on how these funds were expended is not entirely clear.

It is important to recognize that Government taxes, whether official or unofficial, breached or enforced, do not always have the desired effect. In the case of Quang Nam province, due to tax debt and negotiation failures, the Quang Nam authorities have stopped Besra's mining activities in Bong Mieu and Phuoc Son. As a result, on 30 June 2017, Besra communicated complete divestment of all Vietnamese subsidiaries [78] with the future of the mines in question.

\subsection{Environment and Society}

Many mining companies have benefited from land allocation decisions enacted at the provincial level. At the Phuoc Son mine for instance, the company was initially granted over $100 \mathrm{~km}^{2}$ for exploration (Exploration licenses 1953 and 1955/QD-DKCS/1998, granted by the Ministry of Industry) and some of this land was part of a protected forest reserve. In addition, field visits, uncovered that more than USD 500,000 had been spent on economic and social development initiatives between 2010 and 2015 however, these initiatives were not a direct result of legislation. Whilst Besra has seemingly complied with the notion of free, prior, and informed consent (FPIC) [18,79] neither the Mineral Law nor the Environmental Protection Law 2014 directly legislates for the rights of Indigenous People. The mining company has communicated with local communities through the local People's Committee (Letter No 153-09/PSGC/24-09-2009) and, in return, local views were summarized and sent to Besra through two formal letters issued by the People's Committee (Letter No 04/11-01-2010) and the Fatherland Front (Letter No 02/11-01-2010.). However, field observation indicated that without policies requiring mining companies to respond to local stakeholder feedback, it is unlikely that the FPIC process has resulted in genuine consent.

\subsection{Corporate Social Responsibility}

Although Corporate Social Responsibility (CSR) of mining companies is regulated in article 5 of the Mineral Law 2010, the implementation of such initiatives often goes unmeasured. Interviewees 
in the two mining communities (Phuoc Duc and Bong Mieu) highlighted that while CSR initiatives had been enacted by the mining company, they were often viewed as philanthropic rather than 'good practice' on the company's part. Moreover, the effectiveness and motivation of these activities were in questioned by local community members. For example, in a collaboration with a NGO, Besra spent approximately USD 200,000 to build a clean water system for more than 300 houses adjacent to the mine and whose original water supply was at risk of contamination [36]. In addition, interviewees highlighted that after several months of operation, the system was damaged due to flooding and had not been repaired.

The protection of local communities and conflicts with mining companies has remained unaddressed in any of the current mining regulations. In the context of the Phuoc Son and Bong Mieu gold mines, for example, due to environmental pollution, debt, unemployment, lack of transparency, health effects and safety issues, tensions between the local communities and the mining company has arisen [9]. However, without guidance concerning how to handle these situations, 'hot spots' of conflict continue to persist.

\section{Discussion and Conclusions}

\subsection{Regulatory Reform Outcomes}

Over the past decade, mining regulations in Vietnam have been substantially reformed [41]. Importantly, the passing of the Mineral Law 2010 has provided a better regulatory framework for managing the nation's extractive industries. The outcome has been a more strategic and carefully planned process for mineral resource extraction. For example, decision 2427/QD-TTg/22-12-2011 approved by the Prime Minister, provided a fundamental legal framework for mineral resource planning and according to the Ministry of Trade and Industry [80], strategic planning to 2020-2025 has been conducted along with production projects for titanium, bauxite, iron, zinc, coal, copper, gold, and nickel up to 2035.

Similarly, geologic mapping of mineral resources has progressed as an important approach for improving mineral management. For example, decision 1388/QD-TTg/13-08-2013 approved by the Prime Minister, highlighted a set of crucial geologic assessment to provide support for management decision going forward. According to the Ministry of Natural Resources and Environment [33], twenty-four geological mapping projects and mineral evaluations have been completed with more underway. It is anticipated that by $2020,80 \%$ of Vietnam's inland areas will have undergone geologic resource assessments.

As such, mineral resource planning and geologic mapping have provided foundations for better management and licensing for mineral activities. For example, licenses issued by MONRE for approximately 40 minerals were based on geologic resource assessments authorized by the Prime Minister and the Ministry of Trade and Industry. Likewise, licenses approved by the provincial People's Committees for mineral exploration have been based on new detailed geologic resource assessments appropriated by higher authorities.

Notably, regulatory reforms have improved budget contribution to the Government at all levels. According to the National Assembly Economic Commission [41], in the period between 2011 and 2015 , natural resource taxes accounted for $1.02 \%$ of the State's revenue. Similarly, fees for obtaining mineral exploration licenses and collection of expenditures on mineral explorations have substantially contributed to the State's budget. For example, as soon as decree 203/2013/ND-CP came into effect in 2013, the average annual return from licensing has ranged between USD 180,000 and 227,000 [33]. These financial contributions have become important for funding further mineral exploration.

\subsection{Limitations of the Regulatory System}

In Vietnam, there is a complex and extensive regulatory framework in place to provide oversight to the mining industry. However, the nature and extent of regulatory compliance remains a concern [45]. 
This paper found that a substantial gap between policy development and implementation appears to exist based on documentary evidence [45] however, a more focused assessment at the local level does provide insight into regulatory gaps and the nuances therein.

As identified in this paper, corruption and rent-seeking behavior remains a major concern and obstacles for companies trying to comply with the present regulatory frameworks. In 2017, Vietnam was ranked 107 out of 180 nations in perceptions of corruption according to Transparency International [81]. Similarly, in 2017, Malesky, Phan [82] found that 44.6\% of FDI enterprises paid informal fees equating to $31.3 \%$ of annual income. According to [1], this high level of corruption is a result of weak institutions, poor management, delays in economic reform and distortion in the economy.

With the regulations in place, Government officials have limited capacity, time, and resources to detect and deter mining companies from breaching regulations. In terms of taxation, particularly environmental protection fees, Government officials do not possess the infrastructure required to monitor the quality of large volumes of ore [83]. This provides opportunities for mining companies to report smaller quantities and low qualities to avert higher levels of taxation [45]. Similarly, Government officials lack the capacity and policies to determine the real profits earned by mining companies. From, 2010 to 2014, profits reported by mining companies decreased [84] however, the Vietnam Provincial Competitiveness Index (PCI) indicated that mining enterprises were engaging in a process of expansion due to high profit expectations [45].

Research has indicated that the unevenness and complexity in how regulations have been implemented on the ground has led to difficulties for a single mining company to operate multiple sites. At the Bong Mieu mine, the natural resource tax (NRT) was set at $3 \%$, and the corporate income $\operatorname{tax}(\mathrm{CIT})$ at $18 \%$, with eligibility to trade on the domestic market. In contrast, the Phuoc Son mine imposed a NRT of $15 \%$ and a CIT of $40 \%$, and its products could only be exported [83]. Interviews and field observation indicated that as both mines belong to Besra, there is speculation that gold was being transferred from one mine to another to avoid high taxation rates and increase access to the domestic market [83].

The weak institutional environment, particularly in terms of individual responsibility, has also undermined regulatory frameworks. It is often the case that mine management, and political leaders are rarely punished, charged, or dismissed due to poor management, regulatory breaches or corruption. Instead, the notion of 'collective responsibility' has led to a culture of 'no-responsibility' [85]. A financial audit report of Vinacomin [86], indicated that total debt of the State-owned Coal-Mineral Corporation as of 31 December 2016 was more than VND 100,000 billion (estimated USD 5 billion), but no one has been held accountable. Similarly, Besra's tax debt had accumulated to VND 430 billion (estimated USD 21 million) across the two gold mines, yet no individuals have been held responsible (Notice No 207/TB-VPCP/29/07/2016: A meeting between a Deputy-Prime Minister and leaders of Quang Nam province.).

Interestingly, the role of local communities in monitoring mining practices has not been fully appreciated by authorities. In Phuoc Son mine, without the diligence of locals, the illegal discharge of untreated waste water in a local stream would not have been discovered [87]. Similarly, without protests by the Bong Mieu people, the transport of gold ore from Phuoc Son to Bong Mieu for processing would not have been brought to an end. However, field observations suggested that generally speaking, the voices of local communities had not been heard.

In the case of both Phuoc Son and Bong Mieu gold mines, field observation and interviews highlighted that administrative oversight of the two mines had a variety of weaknesses in practice. Specifically, licensing of the mines occurred at the national level however, day-to-day challenges were the responsibility of district and commune authorities. At the same time, local authorities were provided little power in deal with mining related issues, particularly environmental pollution and tensions between the mines and local communities. The capabilities of government agencies to manage the mines was often called into question as interviewees indicated that tax debt, debt to local service providers, inadequate cyanide storage and the release of tailings into the local watershed had all but 
been overlooked by local, regional and federal authorities $[36,88,89]$. Interviewees communicated that the Government had allow the mining company to accumulate a tax debt up to VND 430 billion (estimated USD 21 million) and when the Quang Nam Tax Department attempted to suspend operations at the two mines, Besra viewed this as intimidation tactics [89].

While weaknesses and loopholes in Vietnam's mining regulations are apparent [33], there are continuing challenges for reform. Indeed, regulations are complicated and fragmented (Report No 1642/BC-UBKHCNMT, cited in [45]) and collaboration between Government agencies is ineffective [45]. Policies must be enacted that protect local populations and natural environments. Although, recent reforms have been required to maintain competitive advantage and improve management of the extractive industry, those policies that do provide for sound regulations are often exploited by local and/or the national Government and mining companies alike. Only by addressing these weaknesses will the path be paved for the sustainable growth of Vietnam's mining industry into the future.

\subsection{Future Considerations}

To date, taxes imposed on minerals in Vietnam have been controversial. Murfitt [12] and Vu [57] argued that taxes applied to the mining industry have been large compared to those in other nations. According to the Ministry of Finance (MOF), increasing taxes on natural resources is crucial as previous regulations have been improperly established and inconsistently applied [90]. In consultation with the MOF, the Committee of the National Assembly has supported an increase in mineral resource taxes resulting in more revenue at the national level and better management of natural resource overall [91]. In this context, the concern has been whether increased taxes has helped the State effectively exploit the nation's resources to increase contributions to the national budget [90]. In return, in document No 4949/BTC-CST, the Ministry of Finance confirmed that natural resource taxes had created substantial benefits for the country through effective governance [92]. The extent to which these revenues have supported sustainable development in the country, however, has yet to be determined.

Most importantly, mining communities (and particularly those comprised of Indigenous people) have suffered many negative impacts from resource extraction activities across Vietnam. These include unemployment, low wages [35], health impacts [73], pollution, and limited benefit sharing [9,36]. These impacts can be attributed to weak enforcement of mining regulations, and limited local control over the extraction process. In other countries in the region it appears as if approaches are in place to deal with these issues. In the Philippines, for example, gold mining revenue is taxed at a rate of $29 \%$ with $4 \%$ going to the federal government and $25 \%$ to local communities [26]. In Indonesia, CSR initiatives and community development are legally mandated and mining companies are required to adhere to environmental regulations [93].

Best practices in mineral development and the framework for extractive industries governance developed by the Association of Southeast Asian Nations (ASEAN) are surely applicable to Vietnam (e.g., $[25,94])$ but has not been enacted. Several examples of successful implementation can be identified in the Philippines, Thailand and Indonesia where collaboration with governments have resulted in positive instances of local social and economic development, environmental sustainability, safety and employee welfare [94]. To this end, the legal principles put forth in the framework for extractive industries governance for ASEAN provide a proven foundation [25] from which effective governance could be established.

How to achieve sustainable development goals while opening the door to extractive industries is a challenging proposition for policy makers? Balancing environmental protection and socio-economic growth is an unenviable task and as governments grapple with increasing financial constraints, development initiatives in remote regions are often overlooked. In the Vietnam context, mining is seen as a means to economic growth in the nation's remote expanses however, only through appropriate implementation can this goal be realized in a responsible and sustainable manner. The analysis presented in this manuscript provides a critical review of Vietnam's regulatory reforms and examination of how mining policy has been realized on the ground. Our work identifies 
shortcomings in policy implementation and sector management but also identifies a number of positive examples of how regulatory reform has provided opportunities for enhancing rural development. Vietnam has established the foundation necessary to promote further growth in its mining sector, and with careful management and regular reflection, sustainable development sensitive to the needs of both its people and the environment is possible.

Supplementary Materials: The Supplementary Materials are available online at http://www.mdpi.com/2071-1050/ $11 / 18 / 4861 / \mathrm{s} 1$.

Author Contributions: N.B.N., B.B. and M.T. collectively designed the field study approach; N.B.N. collected information in the field, analyzed the data and wrote the first draft of the manuscript. B.B. and M.T. provided editorial assistance on subsequent drafts of the manuscript including revisions.

Funding: This research was funded by the Australian Government Endeavour scholarship.

Acknowledgments: The authors would like to thank the reviewers for their insightful feedback which has strengthened the paper. This project was supported by an Australian Government Endeavour Scholarship.

Conflicts of Interest: The authors declare no conflict of interest.

\section{References}

1. Weinthal, E.; Luong, P.J. Combating The Resource Curse: An Alternative Solution To Managing Mineral Wealth. Perspect. Politics 2006, 4, 35-53. [CrossRef]

2. Bebbington, A.; Hinojosa, L.; Bebbington, D.H.; Burneo, M.L.; Warnaars, X. Contention And Ambiguity: Mining And The Possibilities Of Development. Dev. Change 2008, 39, 887-914. [CrossRef]

3. Bastida, E. Integrating Sustainability Into Legal Frameworks for Miningin Some Selected Latin American Countries. In Mining, Minerals and Sustainable Development; Centre For Energy, Petroleum And Mineral: Dundee, UK, 2002.

4. Worldbank. Sector Licensing Studies: Mining Sector; World Bank: Washington, DC, USA, 2011; Available online: http://Documents.Worldbank.Org/Curated/En/867071468155129330/Sector-LicensingStudies-Mining-Sector (accessed on 10 November 2017).

5. Cameron, P.D.; Stanley, M.C. Oil, Gas., and Mining: A Sourcebook for Understanding The Extractive Industries; World Bank Publications: Washington, DC, USA, 2017.

6. Campbell, B. Revisiting The Reform Process of African Mining Regimes. Can. J. Dev. Stud. Rev. Can. D'études Dév. 2010, 30, 197-217. [CrossRef]

7. Onorato, W.; Fox, P.; Strongman, J.E. World Bank Group Assistance for Minerals Sector: Development and Reform in Member Countries; World Bank Technical Paper, No. Wtp 405; The World Bank: Washington, DC, USA, 1998.

8. General Statistic Office. Statistic Handbook of Vietnam; General Statistic Office, Statistical Publishing House: Ha Noi, Vietnam, 2014.

9. Nguyen, B.N.; Boruff, B.; Tonts, M. Indicators of Mining in Development: A Q-Methodology Investigation of Two Gold Mines in Quang Nam Province, Vietnam. Res. Policy 2018, 57, 147-155. [CrossRef]

10. Nguyen, N.B.; Boruff, B.; Tonts, M. Mining, Development and Well-Being in Vietnam: A Comparative Analysis. Ext. Ind. Soc. 2017, 4, 564-575. [CrossRef]

11. Fong-Sam, Y. The Mineral Yearbook: The Mineral Industry of Viet Nam. In Survey; United States Geological, US Government: Reston, VA, USA, 2010.

12. Murfitt, R. Reform of The Minerals Law: Clarity of Administrative/Permitting Procedures and Governmental Authority. In Business Issues Bulletin; Vietnam Chamber of Commerce and Industry (Vcci): Hanoi, Vietnam, 2009.

13. Natural Resources and Environment (MONRE); Central Economic Council (CEC); National Assembly Economic Council (NAEC). Tham Luận Hội Thảo: Đánh Giá 5 Năm Thực Hiện Chủ Trương Chính Sách Và Pháp Luật Về Khoáng Sản; Ministry of Natural Resources and Environment/The Central Economic Council/The National Assembly Economic Council: Hànoi, Vietnam, 2017.

14. Bourgouin, F. The Politics Of Large-Scale Mining In Africa: Domestic Policy, Donors, and Global Economic Processes. J. S. Afr. Inst. Min. Metall. 2011, 111, 525-529.

15. Worldbank. Strategy for African Mining; Technical Paper Number 181; Mining Unit, Industry and Energy Division: Washington, DC, USA, 1992. 
16. Worldbank. Mining Strategy for Latin America and Caribbean; Worldbank Technical Paper No. 345; Worldbank: Washington, DC, USA, 1996.

17. Pring, G.; Otto, J.L.; Naito, K. Trends In International Environmental Law Affecting The Minerals Industry. J. Energy Nat. Res. Law 1999, 17, 39-55.

18. UN. United Nations Declaration on The Rights of Indigenous Peoples; United Nations: San Francisco, CA, USA, 2007; Available online: http://Www.Un.Org/En/Genocideprevention/Documents/Atrocity-Crimes/Doc.18_ Declaration\%20rights\%20indigenous\%20peoples.Pdf (accessed on 1 November 2017).

19. Rustad, S.A.; Le Billon, P.; Lujala, P. Has The Extractive Industries Transparency Initiative Been A Success? Identifying And Evaluating Eiti Goals. Res. Policy 2017, 51, 151-162. [CrossRef]

20. Sagebien, J.; Lindsay, N. Governance Ecosystems: Csr in The Latin American Mining Sector; Palgrave Macmillan: New York, NY, USA, 2011.

21. Besada, H.; Martin, P. Mining Codes in Africa: Emergence of A 'Fourth' Generation? Camb. Rev. Int. Aff. 2015, 28, 263-282. [CrossRef]

22. IFC. Performance Standards on Environmental and Social Sustainability; International Finance Corporation: Washington, DC, USA, 2012.

23. Miranda, M.; Chambers, D.; Coumans, C. Framework for Responsible Mining: A Guide to Evolving Standards; Center for Science in Public Participation: Bozeman, MT, USA, 2005; Available online: http://Wedocs.Unep. Org/Handle/20.500.11822/19664 (accessed on 25 October 2017).

24. Goodland, R. Responsible Mining: The Key to Profitable Resource Development. Sustainability 2012, 4, $2099-2126$. [CrossRef]

25. IESR. The Framework for Extractive Industries Governance In Asean; Institute For Essesntial Service Reform: Jakarta, Indonesia, 2014.

26. IESR. Governance of Extractive Industries in Southeast Asia; Institute for Essesntial Service Reform: Jakarta, Indonesia, 2014.

27. Hilson, G.; Hilson, A.; Mcquilken, J. Ethical Minerals: Fairer Trade for Whom? Res. Policy 2016, 49, $232-247$. [CrossRef]

28. NRGI. Natural Resource Charter Benchmarking Framework; Natural Resource Governance Institute: New York, NY, USA, 2017; Available online: Https://Resourcegovernance.Org/Sites/Default/Files/Documents/NaturalResource-Charter-Benchmarking-Framework-Report-2017-Web_0.Pdf (accessed on 10 July 2019).

29. Ambe-Uva, T. Whither The State? Mining Codes And Mineral Resource Governance in Africa. Can. J. Afr. Stud. Revue Can. Études Afr. 2017, 51, 81-101. [CrossRef]

30. Goverment of Vietnam. Mineral Law; Goverment of Vietnam: Hanoi, Vietnam, 2011.

31. Fong-Sam, Y. The Mineral Industry of Vietnam. In 2010 Minreal Yearbook: Vietnam; U.S. Geological Survey: Reston, VA, USA, 2012.

32. National Assembly. Luật Khoáng Sản. In Assembly; 60/2010/Qh12; National Assembly: Ha Noi, Vietnam, 2010; Available online: Http://Vanban.Chinhphu.Vn/Portal/Page/Portal/Chinhphu/Hethongvanban?Class_ Id=1\&_Page=1\&Mode=Detail\&Document_Id=98639 (accessed on 22 October 2017).

33. Monre. Đánh Giá Tình Hình 05 Năm Thực Hiện Chủ Trương Chính Sách Và Pháp Luật Về Khoáng Sản; Ministry of Natural Resources and Environment/The Central Economic Council/The National Assembly Economic Council: Hànoi, Vietnam, 2017.

34. Binh, H.T. Reform of The Minerals Law: Consistent and Fair Fiscal Regime should be Established. In Business Issues Bulletin; Vietnam Chamber of Commerce and Industry: Hanoi, Vietnam, 2009.

35. Tran, T.T.; Nguyen, T.L.; Nguyen, V.D. Khoáng Sản-Phát Triển-Môi Trường: Đối Chiếu Giũa Lý Thuyết Và Thực Tiến; People and Nature Reconciliation: Hanoi, Vietnam, 2012; Available online: http://Nature.Org.Vn/ Vn/2013/05/Khoang-San-Phat-Trien-Moi-Truong/ (accessed on 30 October 2017).

36. Nguyen, N.; Boruff, B.; Tonts, M. Fool's Gold: Understanding Social, Economic and Environmental Impacts from Gold Mining in Quang Nam Province, Vietnam. Sustainability 2018, 10, 1355. [CrossRef]

37. Steven, M.; Fulton, G. Technical Report on Feasibility Studies for the Phuoc Son Gold Project in Quang Nam Province, Vietnam; Olympus Pacific Mineral Inc.: Ha Noi, Vietnam, 2008.

38. Stevens, M.; Fulton, G. Technical Review of Bong Mieu Gold Project in Quang Nam Province; Vietnam for Olympus: Hanoi, Vietnam, 2007.

39. Nguyen, D.A.; Tran, T.T.T.; Tran, T.T.H. Bộ Tiêu Chuẩn Eiti 2013 Và Khả Năng Đáp Ứng Chính Sách Của Việt Nam; Nhà Xuất Bản Hà Nội: Hanoi, Vietnam, 2015. 
40. Prime Minister. Quy Định Chi Tiết Thi Hành Một Số Điều Của Luật Khoáng Sản. In Minister; 15/2012/Nd-Cp; Office of The Prime Minister: Ha Noi, Vietnam, 2012; Available online: http://Vanban.Chinhphu.Vn/Portal/Page/Portal/Chinhphu/Hethongvanban?Class_Id=1\&Mode= Detail\&Document_Id=156031\&Category_Id=0 (accessed on 24 October 2017).

41. Naec. Tăng Cường Vai Trò Giám Sát Của Quốc Hội Trong Việc Thực Hiện Chính Sách, Pháp Luật Về Khoáng Sản. Đánh Giá 5 Năm Thực Hiện Chủ Trương, Chính Sách Và Pháp Luật Về Khoáng Sản; Monre, National Assembly Economic Committee: Hanoi, Vietnam, 2017.

42. Vusta. Thực Trạng Về Quản Lý Khai Thác Và Sủ Dụng Tài Nguyên Khoáng Sản Việt Nam; Vietnam Science and Technology Association: Hanoi, Vietnam, 2012.

43. Monre. Báo Cáo Hoạt Động Khoáng Sản; A Report of Mineral Activities; Ministry of Natural Resources and Environment: Moscow, Russia, 2015.

44. Vo, H.D. Thực Trạng Công Tác Quản Lý Khai Thác Tài Nguyên Thiên Nhiên Ở Nước Ta Và Nhu Cầu Tăng Cường Tính Minh Bạch. 2014. Available online: http://nature.org.vn/vn/wp-content/uploads/2014/07/Prof. -Dang-Hung-Vo.pdf (accessed on 3 October 2017).

45. Dau, A.; Phan, M.T.; Nguyễn, M.D.; Đinh, T. Báo Cáo Về Mức Độ Tuân Thủ Các Quy Định Pháp Luật Về Minh Bạch Trong Lĩnh Vưc Khoáng Sản; Vietnam Chamber of Commerce and Industry and Vietnam Mining Coalition: Ha Noi, Vietnam, 2017.

46. Tran, V.T. Vietnamese Economy at The Crossroads: New Doi Moi For Sustained Growth. Asian Econ. Policy Rev. 2013, 8, 122-143. [CrossRef]

47. Worldbank. Natural Resource Management; Vietnam Development Report 2011; The Worldbank: Hanoi, Vietnam, 2011.

48. Monre. Tổng Kết 13 Năm Thi Hành Luật Khoáng Sản (1996-2009) (A Report Of Thirteen Year to Implement The Mineral Law (1996-2009); Ministry of Natural Resources and Environment: Ha Noi, Vietnam, 2010.

49. Tran, B. Dễ Dãi Cấp Phép Khai Thác Khoáng Sản. Người Lao Động. 2013. Available online: http://nld.com. vn/thoi-su-trong-nuoc/de-dai-cap-phep-khai-thac-khoang-san-20130826100042488.htm (accessed on 30 October 2017).

50. Dau, A.T.; Nguyen, M.D.; Tran, T.T.; Trinh, L.N.; Duong, V.T.; Le, X.T. Thưc Thi Eiti: Để Cải Cách Ngành Công Nghiệp Khai Thác Khoáng Sản Ở Việt Nam; Vietnam Chamber of Commerce and Industry, Vietnam Mining Coalition and Pannature: Ha Noi, Vietnam, 2015.

51. VCCI. Thực Trạng Hoạt Động Của Doanh Nghiệp Khai Khoáng Tại Việt Nam; Vietnam Chamber of Commerce And Industry: Hanoi, Vietnam, 2014.

52. Rgi. The 2013 Resource Governance Index: Vietnam; Natural Resouce Governance Institute: Hanoi, Vietnam, 2013.

53. Sang, H.; Huy, Q. Tôi Đi 'Chạy’ Giấy Phép Khai Thác Mỏ. Vietnamnet. 2011. Available online: http: //vietnamnet.vn/vn/xa-hoi/toi-di--chay--giay-phep-khai-thac-mo-21192.html (accessed on 24 October 2017).

54. Tuyen, P. Lĩnh Vực Khoáng Sản: Khâu Nào Cũng Có Thể Tham Nhũng. Tienphong. 2011. Available online: http://www.tienphong.vn/Print.aspx?id=539362 (accessed on 30 October 2017).

55. Dougherty, M.L. The Global Gold Mining Industry: Materiality, Rent-Seeking, Junior Firms and Canadian Corporate Citizenship. Compet. Chang. 2013, 17, 339-354. [CrossRef]

56. Chen, C.J.P.; Li, Z.; Su, X.; Sun, Z. Rent-Seeking Incentives, Corporate Political Connections, and The Control Structure of Private Firms: Chinese Evidence. J. Corp. Finan. 2011, 17, 229-243. [CrossRef]

57. Vu, M.H. Kêt Quả 5 Năm Thưc Hiện Nghị Quyêt Số 02-Nq/Tu Của Bộ Chính Trị. Đánh Giá 5 Năm Thưc Hiện Chủ Trường Chính Sách Và Pháp Luật Về Khoáng Sản; Ministry Of Natural Resource And Environment: Hànoi, Vietnam, 2017.

58. Le, D.D. Ngành Công Nghiệp Khai Thác Khoáng Sản Ở Việt Nam Còn Nhiều Bất Cập. In Bản Tin Chính Sách: Tài Nguyên-Môi Trường-Phát Triển Bền Vũng; Pannature: Hanoi, Vietnam, 2014.

59. Nam, C.N.; Bich, T.D. Thuế Phí Khoáng Sản Hiện Đang Quá Cao; Vietnam National Coal Mineral Industries Holding Corporation Limited: Hanoi, Vietnam, 2016; Available online: http://Www.Vinacomin.Vn/Tap-ChiThan-Khoang-San/Thue-Phi-Khoang-San-Hien-Dang-Qua-Cao-201608031132109479.Htm (accessed on 18 January 2017).

60. Government. Quy Định Về Phương Pháp Tính, Mức Thu Tiền Cấp Quyền Khai Thác Khoáng Sản. 203/2013/Nđ-Cp. 2014. Available online: http://Vanban.Chinhphu.Vn/Portal/Page/Portal/Chinhphu/ Hethongvanban?Class_Id=1\&Mode=Detail\&Document_Id=171117TheVietnameseGovernment (accessed on 9 October 2017). 
61. Monre. Quy Định Chi Tiết Một Số Điều Của Nghị Định Số 22/2012/Nđ-Cp Ngày 26 Tháng 3 Năm 2012 Của Chính Phủ Quy Định Về Đấu Giá Quyền Khai Thác Khoáng Sản. 201254/2014/Ttlt-Btnmt-Btc. 2012. Available online: http://vanban.chinhphu.vn/portal/page/portal/chinhphu/hethongvanban?class_id=1\& _page=1\&mode=detail\&document_id=176161 (accessed on 21 October 2017).

62. National Assembly. Luật Bảo Vệ Môi Trường in Assembly. 5/2014/Qh13. $2015 . \quad$ Available online: Http://Vanban.Chinhphu.Vn/Portal/Page/Portal/Chinhphu/Hethongvanban?Class_Id=1\&_Page= 1\&Mode=Detail\&Document_Id=175357 (accessed on 23 October 2017).

63. Government. Quyết Định: Về Cải Tạo, Phục Hồi Môi Trường Và Ký Quỹ Cải Tạo, Phục Hồi Môi Trường Đối Với Hoạt Động Khai Thác Khoáng Sản 18/2013/Qđ-Ttg. 2013. Available online: http://Congbao.Chinhphu. Vn/Noi-Dung-Van-Ban-So-18-2013-Qd-Ttg-4013 (accessed on 9 October 2017).

64. Monre. Thông Tư: Về Cải Tạo, Phục Hồi Môi Trường Trong Hoạt Động Khai Thác Khoáng Sản. 38/2015/Tt-Btnmt. 2015. Available online: http://Congbao.Chinhphu.Vn/Noi-Dung-Van-Ban-So-38-2015-TtBtnmt-15380 (accessed on 21 October 2017).

65. Manh, M. Hà Giang: Tổn Thất Tài Nguyên Rừng, Ô Nhiễm Tăng Vì Khai Thác Mỏ. Vietnam Plus. 2015. Available online: http:/www.vietnamplus.vn/ha-giang-ton-that-tai-nguyen-rung-o-nhiem-tang-vi-khaithac-mo/346735.vnp (accessed on 25 October 2017).

66. Monre. Báo Cáo Môi Trường Quốc Gia 2011 Về Chât Thải Rắn; Ministry of Natural Resource and Environment: Hanoi, Vietnam, 2011. Available online: http://Vanban.Chinhphu.Vn/Portal/Page/Portal/ Chinhphu/Hethongvanban?Class_Id=1\&_Page=1\&Mode=Detail\&Document_Id=176161 (accessed on 21 October 2017).

67. Government. Nghị Định: Quy Định Tổ Chức, Bộ Phận Chuyên Môn Về Bảo Vệ Môi Trường Tại Cơ Quan Nhà Nước Và Doanh Nghiệp Nhà Nước. 81/2007/Nđ-Cp. 2007. Available online: https://thuvienphapluat.vn/van-ban/Bo-may-hanh-chinh/Nghi-dinh-81-2007-ND-CP-to-chucbo-phan-chuyen-mon-bao-ve-moi-truong-tai-co-quan-doanh-nghiep-nha-nuoc-20494.aspx (accessed on 3 October 2017).

68. Government. Nghị Định: Quy Định Tổ Chức Các Cơ Quan Chuyên Môn Thuộc Ủy Ban Nhân Dân Tỉnh, Thành Phố Trực Thuộc Trung Ương in 13/2008/NĐ-CP. 2008. Available online: thuvienphapluat.vn:https:/thuvienphapluat.vn/van-ban/Bo-may-hanh-chinh/Nghi-dinh-13-2008-ND-CPto-chuc-co-quan-chuyen-mon-thuoc-Uy-ban-nhan-dan-tinh-thanh-pho-truc-thuoc-Trung-uong-62259.aspx (accessed on 5 October 2017).

69. Government. Quyết Định: Về Ký Quỹ Cải Tạo, Phục Hồi Môi Trường Đối Với Hoạt Động Khai Thác Khoáng Sản in 71/2008/QĐ-TTg. thuvienphapluat.vn; 2008. Available online: https://thuvienphapluat.vn/van-ban/Tai-nguyen-Moi-truong/Quyet-dinh-71-2008-QD-TTG-ky-quycai-tao-phuc-hoi-moi-truong-doi-voi-hoat-dong-khai-thac-khoang-san-66456.aspx (accessed on 6 October 2017).

70. Government. Nghị Định: Về Phí Bảo Vệ Môi Trường Đối Với Khai Thác Khoáng Sản in 63/2008/NĐ-CP. thuvienphapluat.vn; 2008. Available online: https:/thuvienphapluat.vn/van-ban/Thue-Phi-Le-Phi/ Nghi-dinh-63-2008-ND-CP-phi-bao-ve-moi-truong-doi-voi-khai-thac-khoang-san-65781.aspx (accessed on 10 October 2017).

71. Government. Nghị Định: Về Phí Bảo Vệ Môi Trường Đối Với Khai Thác Khoáng Sản in 74/2011/NĐ-CP. thuvienphapluat.vn; 2011. Available online: https:/thuvienphapluat.vn/van-ban/Thue-Phi-Le-Phi/Nghi-dinh-742011-ND-CP-phi-bao-ve-moi-truong-khai-thac-khoang-san-128376.aspx (accessed on 6 October 2017).

72. Vusta. Xung Quanh Việc Triển Khai Các Dự Án Khai Thác Bauxit Ở Tây Nguyên-Nhũng Kiến Nghị Khoa Học; Vietnam Union Of Science And Technology Association: Hanoi, Vietnam, 2009; Available online: http://www.vusta.vn/vi/news/Trao-doi-Thao-luan/Xung-quanh-viec-trien-khai-cac-du-an-khai-thacbauxit-o-Tay-Nguyen-Nhung-kien-nghi-khoa-hoc-29832.html (accessed on 3 November 2017).

73. Lan, H. 'Làng Nhiễm Chì' Dưới Chân Núi Phja Khao. Saigon Online. 2007. Available online: http: //www.sggp.org.vn/SGGP12h/2007/6/103138/\# (accessed on 16 October 2017).

74. Besra. Besra Welcomes Improvements To Vietnam Gold Royalty Law. 2015. Available online: http://Www.Besra. Com/Besra-Welcomes-Improvements-To-Vietnam-Gold-Royalty-Law/ (accessed on 25 September 2017).

75. Government. Nghị Quyết: Về Việc Ban Hành Chương Trình Hành Động Của Chính Phủ Thực Hiện Nghị Quyết Số 02/Nq Tw Ngày 25 Tháng 4 Năm 2011 Của Bộ Chính Trị Về Định Hướng Chiến Lược Khoáng Sản 
Và Công Nghiệp Khai Khoáng Đến Năm 2020, Tầm Nhìn Đến Năm 2030. 103/Nq Cp. 2011. Available online: http://congbao.chinhphu.vn/noi-dung-van-ban-so-103-nq-cp-4814 (accessed on 8 October 2017).

76. Government. Quyết Định: Phê Duyệt Chiến Lược Khoáng Sản Đến Năm 2020, Tầm Nhìn Đến Năm 203. 2427/Qđ Ttg. 2011. Available online: http://Congbao.Chinhphu.Vn/Noi-Dung-Van-Ban-So-2427-Qd-Ttg-794 (accessed on 8 October 2017).

77. National Assembly. Nghị Quyết: Về Việc Ban Hành Biểu Mức Thuế Suất Thuế Tài Nguyên. 928/2010/Ubtvqh12. 2010. Available online: https://Thuvienphapluat.Vn/Van-Ban/Thue-Phi-Le-Phi/Nghi-Quyet-928-2010-Ubtvqh12Bieu-Muc-Thue-Suat-Thue-Tai-Nguyen-105808.Aspx (accessed on 22 October 2017).

78. Besra. Besra Completes Divestment of Vietnam Subsidiaries. 2017. Available online: http://Www.Besra. Com/Vn-Sale-Complete/ (accessed on 26 September 2017).

79. Ilo. C169-Indigenous and Tribal Peoples Convention (No. 169). International Labour Organisation, 1989. Available online: http:/Www.Ilo.Org/Dyn/Normlex/En/F?P=Normlexpub:12100:0::No::P12100_Ilo_Code: C169 (accessed on 20 October 2017).

80. Moti. Tình Hình 5 Năm Thực Hiện Nghị Quyêt 02-Nq/Tư Ngày 25/04/2011 Của Bộ Chính Trị Và Các Tác Động Của Luật Khoáng Sản Năm 2010. Đánh Giá 5 Năm Thực Hiện Chủ Trương Chính Sách, Pháp Luật Về Khoáng Sản; Monre: Hanoi, Vietnam, 2017.

81. Ti. Corruption Perceptions Index; Transparency International: Berlin, Germany, 2017; Available online: https: //Www.Transparency.Org/News/Feature/Corruption_Perceptions_Index_2017 (accessed on 25 October 2017).

82. Malesky, E.; Phan, T.N.; Pham, N.T. The Vietnam Provincial Competitiveness Index: Measuring Economic Governance For Private Sector Development, 2017; Final Report; Vietnam Chamber of Commerce and Industry and United States Agency for International Development: Hanoi, Vietnam, 2018.

83. Pannature \& Oxfam. Quản Trị Bền Vũng Ngành Khai Thác Khoáng Sản Tại Việt Nam Thông Qua Thực Hiện Sáng Kiến Minh Bạch Công Nghiệp Khai Thác (Eiti); Đánh Giá 5 Năm Thực Hiện Chủ Trương Chính Sách Và Pháp Luật Về Khoáng Sản/Monre: Hanoi, Vietnam, 2017.

84. Gso. Sự Phát Triển Của Doanh Nghiệp Việt Nam Giai Đoạn 2010-2014; General Statistics Office: Hanoi, Vietnam, 2016.

85. Vu, T.T.A.; Chirot, L.; Dapice, D.; Huynh, T.D.; Pham, D.N.; Perkins, D.; Nguyen, X.T. Institutional Reform: From Vision To Reality. In Vietnam Executive Leadership Program (Velp); Harvard Kennedy School: Cabridge, MA, USA, 2015.

86. Vinacomin. Báo Cáo Tài Chính Kiểm Toán Cho Năm Tài Chính Kết Thúc Vào 31/12/2016; Vietnam National Coal-Mineral Industry Holding Corporation Limited: Hanoi, Vietnam, 2017.

87. Besra. Besra Resumes Operations At The Phuoc Son Mine In Vietnam After A Temporary Shutdown. 2013. Available online: http://Www.Besra.Com/Besra-Production-Resumes-At-Phuoc-Son/ (accessed on 28 October 2017).

88. Goverment Of Vietnam. Thông Báo 207/Tb-Vpcp: Kêt Luận Của Phó Thủ Tướng Trương Hòa Bình Tại Buổi Làm Việc Với Lãnh Đạo Tỉnh Quảng Nam. 2016. Available online: http://Vanban.Chinhphu.Vn/Portal/Page/Portal/Chinhphu/Hethongvanban?Class_Id=2\&_Page= 1\&Mode=Detail\&Document_Id=185793:VanPhongChinhPhu (accessed on 2 October 2017).

89. Besra. Besra Suspends Operations In Vietnam. 2014. Available online: http://Www.Besra.Com/BesraSuspends-Operations-Vietnam/ (accessed on 27 October 2017).

90. Chung, Q. Tài Nguyên Khoáng Sản Và ... Thuế. Thoi Bao Kinh Te Sai Gon. 2009. Available online: http: //duthaoonline.quochoi.vn/DuThao/Lists/TT_TINLAPPHAP/View_Detail.aspx?ItemID=286 (accessed on 28 September 2017).

91. Lan, N. Bộ Tài Chính Lấy Ý Kiến Về Đề Nghị Nâng Thuế Tài Nguyên. Kinh Te Sai Gon. 2015. Available online: https://www.thesaigontimes.vn/130765/bo-tai-chinh-lay-y-kien-ve-de-nghi-nang-thue-tai-nguyen.html/ (accessed on 30 October 2017).

92. Huyen, K. Chính Sách Tài Chính: Bảo Vệ, Khai Thác, Sử Dụng Hiệu Quả Nguồn Tài Nguyên Khoáng Sản. Thoi Bao Tai Chinh. 2017. Available online: http://thoibaotaichinhvietnam.vn/pages/thoi-su/2017-04-26/chinhsach-tai-chinh-bao-ve-khai-thac-su-dung-hieu-qua-nguon-tai-nguyen-khoang-san-42771.aspx (accessed on 15 October2017). 
93. Devi, B.; Prayogo, D. Mining and Development in Indonesia an Overview of The Regulatory Framework and Policies; Sustainable Minerals Institute, the University of Queensland: Indooroopilly QLD, Australia, 2013.

94. ASEAN. Sustainable Mineral Development: Best Practices in Asean; The Association of Southeast Asian Nations: Jakarta, Indonesia, 2017.

(C) 2019 by the authors. Licensee MDPI, Basel, Switzerland. This article is an open access article distributed under the terms and conditions of the Creative Commons Attribution (CC BY) license (http://creativecommons.org/licenses/by/4.0/). 